\title{
PREFERENSI KONSUMEN BERDASARKAN LABEL SERTIFIKASI HALAL PRODUK PANGAN LOKAL
}

\author{
Suci Nur Utami*1 \\ ${ }^{1,2}$ Program Studi Agribisnis, Fakultas Sains dan Teknologi, Universitas Muhadi Setiabudi Brebes \\ e-mail: *-1 sucinurutami@umus.ac.id
}

\begin{abstract}
Abstrak
Label sertifikasi halal tidak bisa dipisahkan dengan produk pangan di Kabupaten Brebes yang sebagian besar masyarakat merupakan penganut agama Islam. Label halal merupakan bentuk perlindungan bagi konsumen yang peduli pada jaminan halal suatu produk serta meningkatkan kualitas dan keunggulan bersaing bagi produk bagi produsen. Penelitian ini akan mengidentifikasi preferensi konsumen terhadap keputusan pembelian akan produk pangan lokal berlabel sertifikasi halal. Data dianalisis dengan menggunakan analisis regresi linier sederhana. Hasil penelitian menunjukkan bahwa label sertifikasi halal yang telah tercantum dalam kemasan produk pangan lokal di Kabupaten Brebes mempunyai pengaruh terhadap preferensi konsumen dalam keputusan pembelian produk berlabel sertifikasi halal. Namun, tingkat pengaruh dari label tersebut hanya sebesar 28,5 persen yang artinya masih ada variabel lain yang lebih mempengaruhi preferensi konsumen terhadap pembelian produk pangan lokal di Kabupaten Brebes yang tidak dibahas dalam penelitian ini.
\end{abstract}

Kata kunci: preferensi, sertifikasi halal, pangan lokal

\section{PENDAHULUAN}

Mengkonsumsi produk halal merupakan hak dan kewajiban bagi manusia terutama bagi penganut agama Islam. Konsumen cerdas akan lebih memilih produk yang telah terjamin halal dengan melihat adanya label sertifikasi halal pada suatu produk. Label sertifikasi halal yang telah tercantum pada suatu produk merupakan bentuk perlindungan lokal bagi masyarakat yang berfungsi untuk memberikan jaminan bagi konsumen yang peduli pada kehalalan produk dan akan meningkatkan kenggulan bersaing bagi produk tersebut. Label sertifikasi halal dalam tulisan ini adalah pencantuman label halal yang dikeluarkan oleh lembaga berwenang dalam kemasan suatu produk pangan lokal yang ada di Kabupaten Brebes. Label yang tercantum pada kemasan produk terbagi menjadi tiga klasifikasi yaitu sebagai Brand Label yang merupakan merek suatu produk, Descriptive Label yang menggambarkan tentang informasi produk, serta Grade Label yang merupakan penilaian atas suatu produk [1].

Lembaga yang berwenang untuk mengeluarkan label sertifikasi halal adalah Lembaga Pengkajian Pangan Obat-obatan dan Kosmetika Majelis Ulama Indonesia atau LPPOM MUI. LPPOM-MUI bertugas sebagai pengawas produk yang ada di masyarakat dengan label sertifikasi halal untuk menjamin kehalalan suatu produk. Adanya label sertifikasi halal menunjukkan bahwa secara proses, zat-zat yang terkandung dalam produk tersebut telah lolos uji dan bebas dari bahan haram. Label sertifikasi halal pada produk pangan sangat penting untuk diperhatikan oleh karena itu produsen yang mencantumkan label sertifikasi halal pada kemasan produknya bertanggung jawab terhadap halalnya produk tersebut [2].

Indonesia yang mayoritas penduduk muslim belum sepenuhnya menerapkan kewajiban dalam melampirkan label sertifikasi halal yang seharusnya ada dalam kemasan produk utamanya produk pangan. Hal tersebut didasari alasan bahwa konsumen Indonesia masih percaya terhadap informasi -informasi langsung dari produsen atau promotor bahwa tanpa label sertifikasi halal, produk tersebut terjamin kehalalannya [3].

Desain kemasan dan label sertifikasi halal secara etnosentris dari beberapa penelitian yang telah dilakukan akan memberikan pengaruh yang kuat pada minat pembelian konsumen di

Submitted: Juni 2021, Accepted: Juli 2021, Published: Juli 2021

ISSN: 2775-247X (online), Website: http://jurnal.umus.ac.id/index.php/jtfp 
tingkat nasional maupun internasional. Akan tetapi, tidak sepenuhnya terjadi pada produk pangan terutama produk pangan lokal yang diproduksi oleh UMKM-UMKM di wilayah Kabupaten Brebes. Merujuk pada observasi yang telah dilakukan dalam penelitian lain, konsumen umumnya membeli produk pangan lokal karena harga yang cenderung lebih murah ditambah dengan kemudahan akses dalam memperoleh produk tersebut [4].

Ketidakinginan masyarakat penganut agama Islam dalam mengkonsumsi pangan haran akan mendorong peningkatan atau pertimbangan yang lebih tinggi dalam memilih suatu produk. Akan terjadi suatu proses dimana ada pemilihan produk yang dikonsumsi dan akan ada produk yang tersisih. Salah satu parameter dalam pemilihan tersebut adalah label sertifikasi halal suatu produk. Kenyataannya, masih banyak produk yang tidak mencantumkan label sertifikasi halal dalam kemasannya dan banyak di kalangan masyarakat yang tidak mempertimbangkan ada tidaknya label sertifikasi halal dalam kemasan suatu produk sehingga mereka cenderung tetap mengkonsumsi produk tersebut [5]. Hal tersebut akan memunculkan suatu permasalahan dimana terdapat kesenjangan antara produk yang telah mencantumkan label sertifikasi halal dengan produk yang belum tersertifikasi halal.

Penelitian ini membahas mengenai pentingnya label sertifikasi halal yang harus ada dalam suatu kemasan produk utamanya pangan lokal. Label sertifikasi halal akan memberikan perlindungan bagi produsen dari adanya tuntutan bahan maupun proses yang tidak halal dalam proses produksi dan akan melindungi konsumen sehingga tidak muncul keraguan dalam mengkonsumsi suatu produk yang tentunya akan menambah kepastian kehalalan dan rasa aman dalam mengkonsumsi produk tersebut.[6]

Hipotesis dalam penelitian ini adalah Label sertifikasi halal akan meningkatkan preferensi konsumen terhadap keputusan pembelian produk pangan lokal yang ada di Kabupaten Brebes.

\section{METODE PENELITIAN}

\subsection{Jenis Penelitian}

Penelitian ini merupakan jenis penelitian deskripsi kuantitatif yang menginterpretasikan data yang diperoleh untuk menarik suatu kesimpulan dari data tersebut. Penelitian menggunakan metode survei yang akan megidentifikasi preferensi konsumen sebagai variabel independent terhadap keputusan ppembelian produk berlabel sertifikasi halal sebagai variabel dependent.

\subsection{Teknik Penentuan Responden}

Responden yang digunakan dalam penelitian ini adalah konsumen produk pangan lokal yang telah berlabel sertifikasi halal sejumlah 120 responden yang tersebar di beberapa wilayah Kabupaten Brebes. Penentuan responden menggunakan metode purposive sampling dengan teknik nonprobability sampling.

\subsection{Teknik Pengumpulan Data}

Data yang digunakan terbagi menjadi dua jenis data yaitu data primer dan data sekunder. Pengumpulan data primer dengan menggunakan metode observasi dan wawancara dengan alat bantu kuesioner untuk mengumpulkan data yang ada di lapangan. Observasi dilakukan dengan mengamatisecara langsung di lapangan untuk mengetahui preferensi konsumen pada pembelian produk pangan yang telah mencantumkan label sertifikasi halal dalam kemasan produk. Kemudian melakukan wawancara supaya terjadi komunikasi langsung dengan konsumen. Proses wawancara dibantu dengan menggunakan instrumen berupa kuesioner terhadap responden. Pernyataan identitas dan variabel dimasukkan dalam skala likert dengan skor 1 s.d. 5 sesuai kriteria sebagai berikut: 
Skor $5 \quad$ Sangat Setuju (SS)

Skor $4 \quad$ Setuju (S)

Skor $3 \quad$ Netral (N)

Skor 2 Tidak Setuju (TS)

Skor $1 \quad$ Sangat Tidak Setuju (STS)

Pengumpulan data sekunder melihat data-data yang telah tersedia dan tersimpan di instansi-instansi yang terkait dengan penelitian ini. Data yang dimaksud adalah data yang diperoleh dari Dinas Koperasi, Perdagangan, dan Usaha Mikro, Kecil, dan Menengah (Dinkopumdag) Kabupaten Brebes untuk mengetahui data UMKM pangan ada di Kabupaten Brebes.

\subsection{Analisis Data}

Teknik analisis data dengan analisis regresi linier sederhana untuk mengidentifikasi preferensi konsumen terhadap keputusan pembelian produk pangan lokal yang berlabel sertifikasi halal. Rumus regresi linier sederhana adalah sebagai berikut:

$$
\mathrm{Y}=\mathrm{a}+\mathrm{bX}+\mathrm{e}
$$

Keterangan:

$\mathrm{Y} \quad$ : variabel dependen

a : konstanta

b : koefisien regresi

$\mathrm{X}$ : variabel independen

e : error

Rumus tersebut dimodifikasi sesuai kebutuhan penelitian yaitu:

$$
\mathrm{P}=\mathrm{a}+\mathrm{bLH}
$$

Keterangan:

$\mathrm{P} \quad$ : Preferensi konsumen

a : Konstanta

b : Koefisien regresi

LH : Label halal

\section{HASIL DAN PEMBAHASAN}

\subsection{Hasil Penelitian}

Penulis memperoleh tanggapan dari responden berupa pernyataan atas kriteria yang telah ditentukan sebelumnya dari setiap variabel penelitian. Hasil analisis statistik yang diperoleh adalah sebagai berikut:

Tabel 1. Hasil Analisis Regresi Linier Berganda

\begin{tabular}{lccl}
\hline \multicolumn{1}{c}{ Variabel } & b & t & Sig. \\
\hline Konstanta & 2,267 & 1,011 & .251 \\
Label Sertifikasi Halal & 0,283 & 5,729 & .000 \\
\hline
\end{tabular}

$\mathrm{R}^{2}$ sebesar 0,285

Sumber: Data primer terolah, 2021 
Persamaan regresi linier sederhana yang dapat dilihat berdasarkan tabel 1 adalah:

$$
\mathrm{P}=2,267+0,283 \mathrm{LH}
$$

Berdasarkan persamaan tersebut, didapatkan hasil bahwa nilai konstanta (preferensi konsumen) yang belum dipengaruhi oleh pencantuman sertifikasi label sertifikasi halal adalah sebesar 2,267. Sedangkan koefisien regresi linier label sertifikasi halal dapat diartikan bahwa pencantuman label sertifikasi halal memberikan pengaruh yang positif pada preferensi konsumen. Apabila koefisien regresi naik satu persen maka preferensi konsumen akan meningkatkan sebesar 0,283 persen. Pencantuman label sertifikasi halal dalam kemasan suatu produk utamanya produk pangan lokal akan memberikan beberapa manfaat antara lain meningkatkan tingkat kepercayaan konsumen serta menjadikan konsumen yakin akan produk yang dikonsumsi. Sisi produsen, label sertifikasi halal dapat dijadikan sebagai alat bantu promosi dan ekspansi pemasaran ke penyalur yang lebih besar [7]. Korelasi label sertifikasi halal terhadap preferensi konsumen dalam mengkonsumsi suatu produk merupakan penyempurna yang dibutuhkan oleh konsumen terutama konsumen muslim [8].

\subsection{Koefisien Determinasi $\left(\mathbf{R}^{2}\right)$}

Berdasarkan hasil analisis diperoleh nilai koefisien determinasi $\left(\mathrm{R}^{2}\right)$ sebesar 0,285 yang artinya 28,5 persen label sertifikasi halal. Melihat angka tersebut, dapat dikatakan bahwa label sertifikasi halal tidak terlalu mempengaruhi preferensi konsumen terhadap keputusan pembelian produk pangan yang berlabel sertifikasi halal. Terdapat beberapa indikator lain yang menjadi pertimbangan konsumen dalam memilih produk pangan yang dikonsumsi. Hasil tersebut diperkuat dengan hasil penelitian Izzuddin (2018) bahwa label halal tidak berpengaruh terhadap minat beli konsumen terhadap pangan lokal yang umumnya masih menggunakan kemasan tradisional [3]. Pernyataan tersebut juga diperkuat dengan penelitian lain yang menyatakan bahwa tidak terdapat pengaruh antara label halal dengan keputusan pembelian produk makanan halal. Penelitian yang menggunakan mahasiswa sebagai sasaran menghasilkan kesimpulan mayoritas mahasiswa tidak melihat label yang ada dalam kemasan produk yang mereka beli karena adanya kepercayaan dan anggapan bahwa makanan yang dijual dalam lingkungan islami sudah terjamin kehalalannya [9]. Indikator lain yang mempengaruhi keputusan pembelian konsumen menurut Willy (2019) adalah desain kemasan produk yang meliputi nama merek, tipografi, warna, gambar dengan persepsi tinggi serta informasi mengenai masa edar produk yang artinya konsumen sudah lebih cerdas dalam pengambilan keputusan untuk mengkonsumsi suatu produk [10].

\subsection{Uji Parsial (Uji t)}

Uji t yang merupakan uji secara parsial terhadap satu variabel merupakan suatu pengujian untuk mengetahui tingkat pengaruh dari variabel independen terhadap variabel dependen secara signifikan dengan asumsi variabel lain dianggap konstan atau tidak berpengaruh secara signifikan [6].

Seperti yang ada dalam tabel 1, diketahui t hitung sebesar 5,729 lebih besar dari thitung. Artinya label sertifikasi halal mempunyai pengaruh terhadap preferensi konsumen dalam pembelian produk pangan lokal yang berlabel sertifikasi halal.

\section{KESIMPULAN}

Kesimpulan yang dapat diambil dari hasil penelitian adalah label sertifikasi halal yang telah tercantum dalam kemasan produk pangan lokal di Kabupaten Brebes mempunyai pengaruh 
terhadap preferensi konsumen dalam keputusan pembelian produk berlabel sertifikasi halal. Namun, tingkat pengaruh dari label tersebut hanya sebesar 28,5 persen yang artinya masih ada variabel lain yang lebih mempengaruhi preferensi konsumen terhadap pembelian produk pangan lokal di Kabupaten Brebes yang tidak dibahas dalam penelitian ini.

\section{SARAN}

Terdapat beberapa hal yang perlu disarankan sebagai hasil dari penelitian diantaranya adalah perlunya peningkatan desain kemasan UMKM termasuk label sertifikasi pangan terutama untuk UMKM bidang pangan untuk menambah minat konsumen. Bagi peneliti yang akan meneliti lebih lanjut sebagai penyempurnaan penelitian ini adalah disarankan untuk mencari variabel lain yang mempengaruhi tingkat preferensi konsumen terhadap keputusan pembelian suatu produk pangan

\section{DAFTAR PUSTAKA}

[1] T. P. L. Bulan, "Pengaruh Labelisasi Halal terhadap Keputusan Pembelian Sosis di Kuala Simpang Kabupaten Aceh Tamiang," J. Manaj. dan Keuang. Unsam, vol. 5, no. 1, hal. 431-439, 2016.

[2] Y. Rambe dan S. Afifuddin, "Pengaruh Pencantuman Label Halal pada Kemasan Mie Instan terhadap Minat Pembelian Masyarakat Muslim (Studi Kasus pada Mahasiswa Universitas Al-washliyah, Medan)," J. Ekon. dan Keuang., vol. 1, no. 1, hal. 14866, 2012.

[3] A. Izzuddin, "Pengaruh Label Halal, Kesadaran Halal, dan Bahan Makanan terhadap Minat Beli Makanan Kuliner," J. Penelit. Ipteks, vol. 3, no. 2, hal. 100-114, 2018.

[4] K. Trifiyanto, "Masa Depan Produk Lokal: Analisis Pengaruh Etnosentris Konsumen, Desain Kemasan, dan Persepsi Labelisasi Halal terhadap Minat Pembelian Produk Lokal," J. Fokus Bisnis, vol. 17, no. 02, hal. 15-24, 2018.

[5] I. Alfian dan M. Marpaung, "Analisis Pengaruh Label Halal, Brand, dan Harga terhadap Keputusan Pembelian di Kota Medan," At-Tawassuth, vol. 2, no. 1, hal. 122-145, 2017.

[6] S. H. Sahir, A. Ramadhan, dan E. D. S. Tarigan, "Pengaruh Gaya Hidup, Label Halal Dan Harga Terhadap Keputusan Pembelian Kosmetik Wardah Pada Mahasiswa Program Studi Manajemen Fakultas Ekonomi Universitas Medan Area Medan,” J. Bisnis dan Manaj., vol. 2, no. 031, hal. 130, 2018.

[7] A. F. Kartika, "Fenomena Label Halal is it a Awareness or Branding," J. Ilm. Ekon. Islam, vol. 6 , no. 1 , hal. $87,2020$.

[8] G. Hanifah, N. K. Khanifa, dan I. Ariono, "Korelasi Label Halal Produk Kosmetik terhadap Minat Beli Konsumen Perspektif Maslahah," Syariati, vol. VI, no. 2, hal. 160$170,2020$.

[9] Y. A. Nurohman dan R. S. Qurniawati, "Keputusan Pembelian Produk Makanan Halal di Lingkungan IAIN Surakarta," Among Makarti, vol. 12, no. 24, hal. 23-33, 2019.

[10] W. Willy dan S. Nurjanah, "Pengaruh Kemasan Produk Dan Rasa Terhadap Minat Beli Yang Berdampak Pada Keputusan Pembelian Pelanggan Minuman Energi," J. Ilmu Manaj., vol. 8, no. 2, hal. 65, 2019. 